\title{
Fair Value Assessment of Private Hostels and Residential Conflicts on Navrongo Campus, University for Development Studies, Ghana
}

\author{
Luu Yin \\ Faculty of Mathematical Science, \\ University for Development Studies, Navrongo, Ghana \\ Email: luuyin20o6@yahoo.co.uk \\ DOI: http://dx.doi.org/10.4314/gjds.v11i1.6
}

\begin{abstract}
This research examined the fair value of hostels in Navrongo. The problem investigated and addressed is increasing conflict prevalent among hostel owners and their student tenants in the Navrongo Campus of UDS. The research design applied was the Mixed Method under the multiple methods choices. A sample of sixty respondents made up of forty hostel owners ${ }^{7}$, sixteen students and four management staff were involved in the study. The findings were that Hostels within the University environs were over priced due primarily to information asymmetry. When landlords fail to deliver on their promises of better facilities, some of the students feel cheated and react assertively. The Thomas-Kilmann Conflict Mode Instrument (TKI) revealed that at the point of conflict the parties are at a high assertiveness. By breaking the information asymmetry, students had the opportunity to make informed choices. It is recommended among other that the Students' Representative Council (SRC) should continuously update the hostel profiles and publish it in the internet for easy access by fresh students.
\end{abstract}

Key words: Fair value, Private Hostels, Duty of Care, Conflict, and Conflict Management

\section{Introduction}

The introduction of cost sharing in tertiary institutions in Ghana started at a time when the economy was undergoing some structural adjustment. This was a necessary evil that was only understood by government and its policy makers. Parents, students and other stakeholders of tertiary education had to accept and abide by it because there was the need for everyone to contribute for the building of mother Ghana.

7 Hostel owners, landlords and hostel operators are used interchangeable here to mean the same group of respondents. 
The introduction of Academic Facilities User Fees in the mid 1990s (AFUF) climaxed the tertiary education cost sharing. Government, since this point in time, shifted its focus from developing students' residential accommodation to academic facilities in the universities. Some students were made non-resident full time on-campus ${ }^{8}$ students. These students were compelled to look for accommodation outside the university community.

The Navrongo Campus has about 6o percent (that is, 1920 out of 3219) registered student population living in private hostels. Very little is known about these hostels. Between 2009 and 2012 academic years there were increasing rates of conflict between hostel operators and student tenants. Some students were beaten, locked up in police custodies, and suffered other types of humiliations. Landlords also had their fair share of increasing bad debts on rent incomes, prosecutions in rent control offices and student tenants deliberately causing damage to hostel facilities and/or misuse of utilities.

The increasing rate of conflicts between private hostel owners and students is the research problem the study seeks to investigate.

\section{Theoretical Framework}

\section{Causes of Conflict between Landlords and Student-tenants}

Conflict is a disagreement, and is when one party is perceived as preventing or interfering with the goals or actions of another. CIMA (2010) classified the causes of conflict into horizontal or vertical. The horizontal causes cover all differences associated with groups or parties of equal hierarchy. Some of the hazards that can fuel possible horizontal conflict include the creation of competitive environment fused with interdependent tasks, a reward system with undefined activities, functional specialisation that generates differences in cognitive and emotional orientations.

The vertical causes of conflict on the other hand, arise between parties at different levels in the hierarchy. Although some of the horizontal causes may apply under the vertical causes, vertical causes are mostly associated with: power and status, ideology, psychology and scarce resources.

Mainwaring (1999) admitted that conflict has varying causes. He identified history, differences, limited resources, win/loss situations, interdependencies, misunderstanding, conviction beliefs, stress and failure, and change as the key causes of conflict. Historical causes are those that have the tendency of being self-perpetuating. Conflicts caused by differences are mainly conflicts associated with interests, objectives, priorities, and

8 Full time on-campus students are the regular or mainstream students who are assumed to be resident within the peripherals of the university community. They are mostly accommodated in halls of residence or hostels owned or managed by the university or privately owned and managed hostels that are accredited by the university authorities. 
ideologies differences between the parties. Change which creates new relationships, objectives, perceptions, problems, and possibilities for individuals, groups, organisations and societies is a sufficient reason to generate conflict. According to CIMA (2010), Dessler identified competition for shared resources; differences in goals, values and perceptions; group's authority not in balance with their responsibility; and ambiguous or unclear roles and responsibilities as the four major sources of conflict.

The issue of concern under this objective is to determine the specific variables that are causing the conflict between the hostel owners and the students. Does it have anything to do with the students seeking some kind of freedom in the hostel? Are landlords cohabiting in the hostels and intruding into students affairs? Do hostel owners restrict the utilization of certain facilities in the hostels? Are some promised services that are paid for not available or forthcoming? Are students accepting other students to stay in their rooms and therefore over stretching the facilities in the hostels? These and many other questions were raised to elicit information on the causes of the increasing rate of conflict between students and their hostel owners.

\section{Fair Value Assessment of Rents}

From a finance view point, fair value is in principle the expected market value of an asset. Fair value gives at each instant a seemingly relevant liquidation value but obscure the value creation process by mixing present profit with unrealized capital gains and losses (Boyer, 2007). Paradoxically fair value principles exchange a deterioration of everyday information quality against a less inaccurate assessment of the valuation of the firm, were it to be liquidated today, a rather unlikely event. A second and derived argument points out that the discrepancy generated by fair value is increasing with the degree of uncertainty, at odds with the widely held belief about the efficiency of existing financial markets to cope with uncertainty and the intrinsic merits of fair value.

Given the intrinsic imperfection of hostels market in Navrongo, fair value is likely to reinforce the accelerator effect of facilities improvements. Typically it is bound to generate new reverberation effects between the evaluation of the hostels' facilities and market valuation of their services or facilities. The instability typical of a largely, if not fully, liberalized financial systems could be exacerbated by the shift from historical costs to market valuation of non financial firms assets. Unless the recognition of this shift of the risk to new actors triggers a new wave of financial innovations in order to counteract the factors of financial fragility brought in by the adoption and diffusion of fair value.

\section{The Concept of Duty of Care}

The concept of duty of care is associated with the legal principle of tort of negligence. The word Tort is from a Lartin word "Tortus" meaning a wrong (Clark, L.S., Kinder P.D. \& Hotchkiss C., 1988). So the law of tort is the law of wrongs developed under the common 
law. However tort is distinguished from other legal wrongs. The tort of negligence arises when a loss is caused by a failure to take reasonable care when there is a duty to do so. In the case of Donoghue $v$ Stevenson 1932 the House of Lords ruled that a person might owe a duty of care to another with whom he had no contractual relationship at all.

In this landmark case of Donoghue v Stevenson (1932) A.C 562, the House of Lords established that a general duty of care could be applied to all subsequent cases and situations even where there is no contract between the parties - this duty states that everyone has a duty not to cause foreseeable harm to foreseeable victims. This duty is known as the neighbour principle and was given by Lord Atkin as guidance for future cases.

As reported by McGirt (1999), universities owe no inherent duty of care to its students and as such no university has been held liable for injuries sustained by a student while he/ she is on school grounds. This is probably because there are no special circumstances or relationships that impose a duty of care toward a student on a university. The courts have been reluctant to find a special relationship between students and universities under the view that university students are self-sufficient adults. They are viewed as adults who are capable of taking care of themselves and taking responsibility for their decisions.

The courts have, however, recognized three areas in which universities owe a duty to their students. The three theories under which courts have recognized such a duty are the: loco parentis doctrine; landowner-invitee theory; and student-college relationship as special.

\section{Loco Parentis Doctrine}

According to Hirshberg, (1994) when universities were stressing discipline and structure, the common law in loco parentis doctrine emerged and colleges were assigned a duty to supervise the actions of their students. The courts deferred to colleges and universities and allowed a great amount of leeway. Under the doctrine, a university owes students a duty of protection because the university stands "in place of the parents." Although the university owed the students a due of care, because they stood in the place of parents, the courts were reluctant to intervene just as they were reluctant to allow a child to sue a real parent. As in Illinois ex rel. Pratt v. Wheaton College, (1866) a discretionary power had been given to college authorities to regulate the discipline of their college in such a manner as they deem proper (.... "We have no more authority to interfere than we have to control the domestic discipline of a father in his family.").

\section{Landowner Invitee Theory}

This theory imposes liability on the landowner when a reasonably foreseeable crime or injury occurs on the land of the land owner (the university) and the invitee (the student) suffered it while on campus. Courts were forced to find an avenue in which universities owed a duty to their students. The concept creates some "special relationship" of landowner-invitee between colleges and students. The imposition of a duty of care 
liability under the landowner-invitee theory, do not arise automatically because the injury was reasonably foreseeable alone, but that it was suffered by the plaintiff while honouring an invitation by the landowner.

\section{The Student-College Relationship as Special}

In the absence of a special relationship, a defendant owes no duty to a plaintiff. Even in cases where special relationships are created the law is reluctant to hold the universities liable. These special relationships often come into existence because one party depends on the other or the parties are mutually dependent such as common carrier and passenger or innkeeper and guest (Davis, 1992).

\section{Methodology}

\section{The Research Design}

The research design is the Mixed Method under the Multiple Methods Choices (Curran \& Blackburn, 2001; Tashakkori \& Teddlie, 2003). Under this research design, a single research study may use quantitative and qualitative techniques and procedures in combination. The techniques applied in this study are an anthropological exploration and a statistical survey.

The anthropological approach to research is characterised by unstructured interviews, critical observations and keeping of a detail analytical field notes, recording the experiences and observations (Whiting \& Whiting, 1973).

\section{The Population of the Study}

The study population covers all houses designated as hostels within the environs of the university. This population covers a very significant proportion of building structures constructed in the surroundings of the university. About 80 percent of new houses in the university surroundings are specifically designed and built for hostel businesses, except the few existing indigenously designed buildings which accommodated endogenous families over the years.

\section{The Sample of the Study}

The sample for the study was purposively selected from Students' Representative Council (SRC), the owners of houses designated as hostels in the university surroundings and some university staff. The sample size of 60 respondents used for the study, were from all the 40 sampled hostels, sixteen students including two representatives of the SRC and four members of the Campus Housing Committee, which included a Senior Hall Tutor, the Campus Counsellor, and two other members. The entire sixty respondents were involved in all aspects of the study. 
The rationale for the section of this sample was to ensure full participation of respondents especially with the hostel. The staff respondents were more of informants due to their close working relationship with the non-resident student body. The student representatives were leaders of the student body who were all non-resident student and were very conversant with the conditions in the private hostels, hence the purposive sampling of the respondents.

\section{The Data Collection Techniques}

The use of both quantitative and qualitative research design methods necessitated the collection of both qualitative and quantitative data. By the anthropological approach, the informants were invited to a meeting on the university campus. After briefing them of the purpose of the meeting they were put in groups of eight to discuss and present the various challenges they encounter in their hostels, their expectations from the university as well as the students, and other service providers in their businesses as hostel operators. Each hostel was later visited within a given time frame. During the visitation the researcher spent a minimum of one hour with the informant during which direct and critical observation and unstructured interviews were carried out. Detailed analytical notes were made covering the data gathered from each informant.

The students were met as focus groups, two days after meeting the Hostel Operators. In addition to the focus group discussions held with each category of respondents, a set of questionnaire was administered to each respondent to elicit answers covering the pertinent issues. The questions were both close and open ended. A 100 percent response rate was recorded in this survey.

\section{The Method of Data Analysis}

The study design adopted the mixed methods and therefore used qualitative and quantitative data collection techniques. The deduction approach was applied in the data analysis. Under this approach, questions generated from the study objectives were expressed in operational terms and tested. (Robson, 2002). Tables and charts were generated to explain the quantitative data.

The Thomas-Kilmann Conflict Mode Instrument (TKI) - de-personalising conflict and resolving issues was used to analyse the conflict situation and generate strategies for its minimisation if not eradication. The tool identifies four main quadrants of conflict stages, namely, avoidance, accommodation, collaborative and competitive. Avoidance and accommodation are both characterised by low assertiveness where one of the parties to the conflict has more concern for the other party's interest than his/her own interest. This easily gets solved within the conflicting parties.

The competitive and collaborative quadrants are on the other hand, are at high assertive zone. Parties have greater concern for themselves and little or no concern for the other party. Although collaborative has high assertiveness, the higher desire to cooperate with 
the other party generates a prospect of waving some of his demands for the benefit of the other party but without trading his/her significant benefits. The conflicting parties passionately confront the causes of the conflict holding tight their own interest. The arbitrator must be capable of negotiating a trade-off so as to generate a win-win for both parties. When this negotiation fails, then a compromise is sought for. The compromise stand arises when the rights, benefits and losses of both parties are addressed proportionally during the conflict resolution. The parties are encouraged to assume moderate position in both assertiveness and cooperativeness. The goal is to find a middle ground as exhibited by the position of the compromise box in figure one.

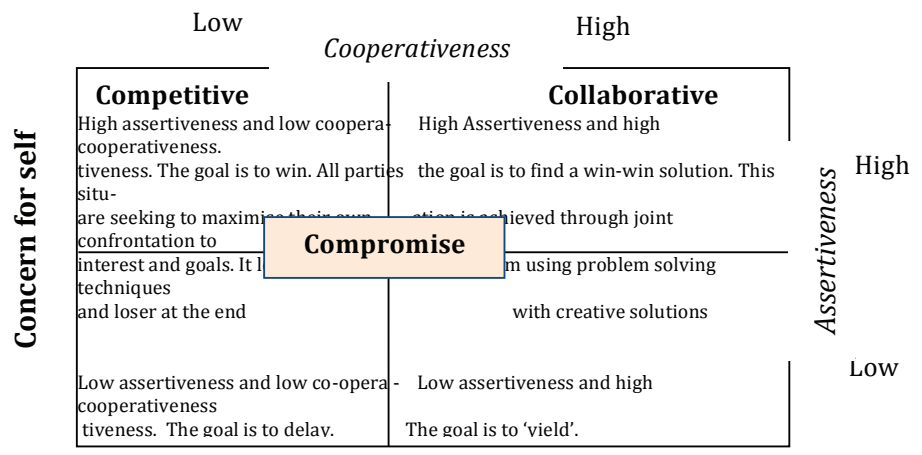

Concern for Others

\section{Figure 1: TKI conflict analysis and resolution tool}

Source: CIMA, 2010

Negotiations result in each party giving up something and meeting half way. The problem is that each party suffers an opportunity cost for the sake of the other although there could have been a better alternative.

\section{Research Findings, Analysis and Discussion}

\section{Background Characteristics of the Respondents and their Businesses}

The University for Development Studies is the first multi-campus university established by the Government of Ghana in 1992. It currently has campuses in Nyankpala, Tamale, Navrongo and Wa. The Navrongo campus has two faculties - that is Faculty of Applied Sciences and Faculty of Mathematical Sciences. In the 2012-2013 academic year, the Campus had a student population of 3,219. It also has three halls of residence consisting of two males' halls and one for the female. All the three halls have 332 rooms for a maximum of $332 \mathrm{X}_{4}=1328$ students, assuming four students were accommodated in each of them. 
The sampled respondents were 60 and consisted of 40 hostel owners, 16 student tenants and 4 staff members of the university. This is represented in figure two.

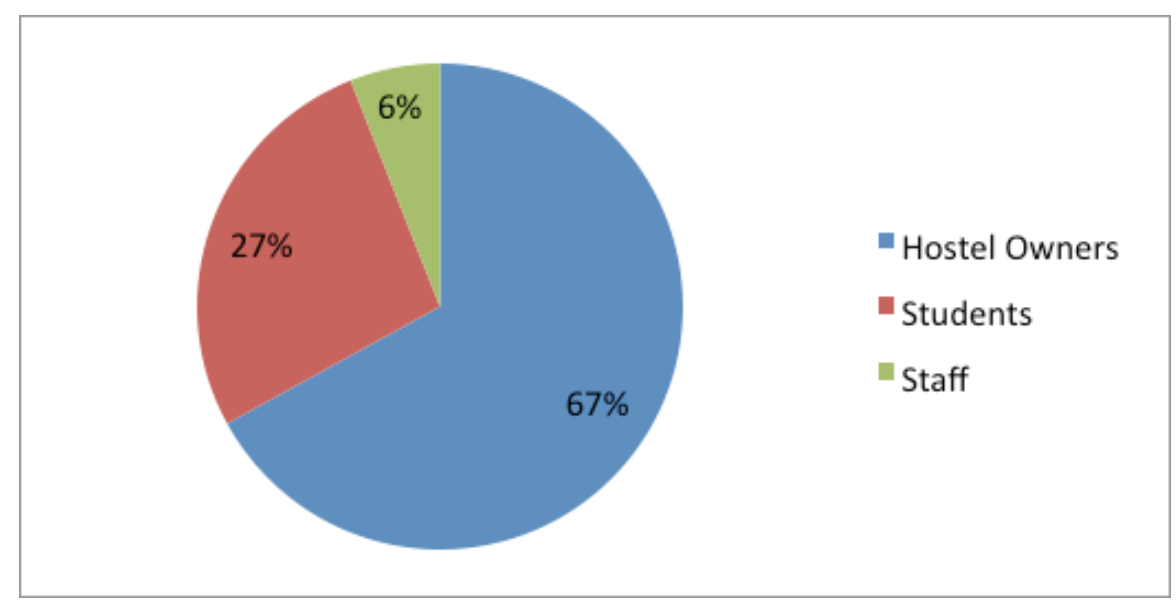

\section{Figure 2: Representation of respondents}

Source: Research Survey, 2013

\section{Gender and Marital Status of Respondents}

The Hostel owners were dominated by females (55\%). While all the males were married only 45 percent of the females were married. Although only 45 percent of the females were married all of them had their own children they are catering for. About eight percent of the singled mothers were either divorcees or widows, but the rest never married before. There was no record of a single father among the hostel owners.

\section{Age Distribution of Respondents}

The youngest hostel owner was 21 years who inherited from his late mother. As shown in figure three most of the hostel owners were within the age range of 31 to 45 . These age groups are typical of entrepreneurial exploration due to the responsible status of people of those ages. Thus persons in those ages are normally the family bread-winners. 


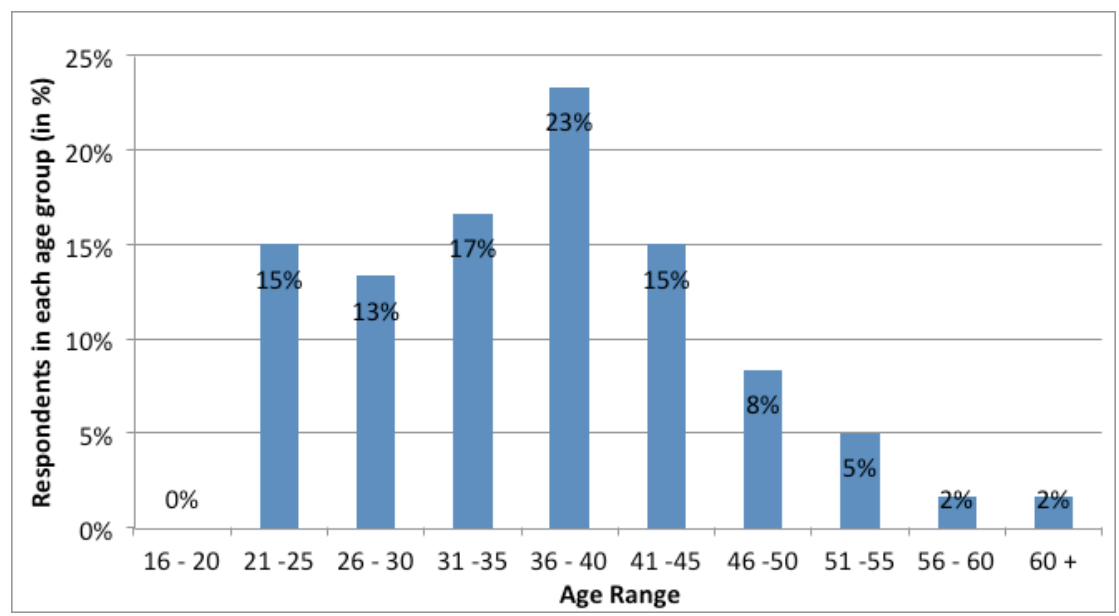

\section{Figure 3: Age distribution of respondents}

Source: Research Survey 2013

\section{Educational Status of Respondents}

All the hostel owners except 2 (5\%), had formal education to at least Middle School Leaving Certificate which is now equated to Junior High School. Figure 4.3 indicates that majority of the hostel owners had senior high school followed by those with tertiary education. No $\mathrm{PhD}$ holder owned any of the sampled hostels.

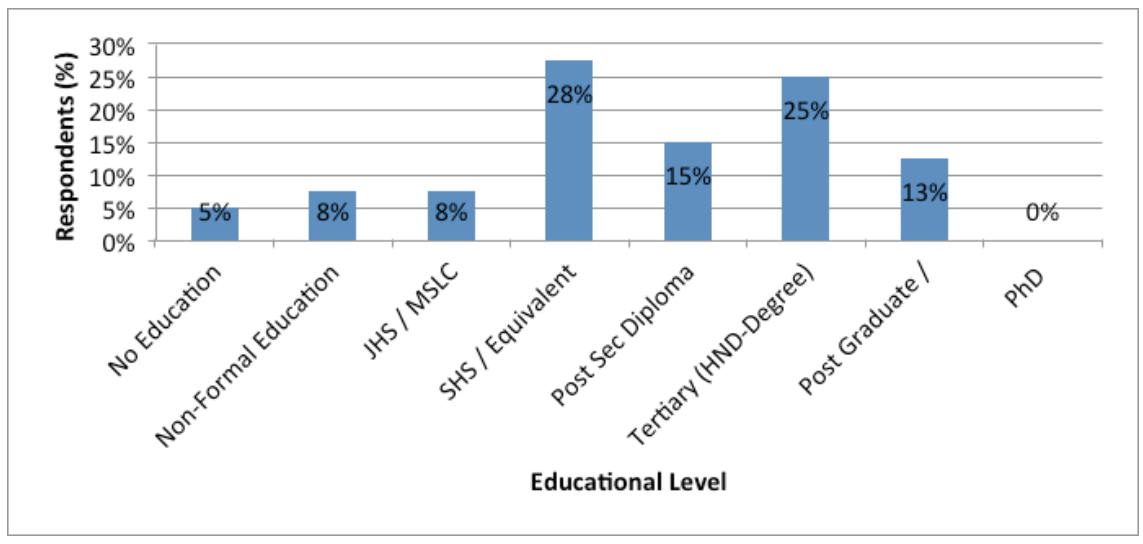

\section{Figure 4: Educational status of hostel owners}

Source: Research Survey, 2013 
Over 80 percent of the hostel owners were natives of the Kasena -Nankana area. The students were ethnically diverse and dominated by males. All the 16 student respondents were those in their $2^{\text {nd }}, 3^{\text {rd }}$ or $4^{\text {th }}$ years in the University. First year students had not reported at the time of collecting the data, so they could not be included.

\section{The Causes of Conflict between the Hostel Owners and their Student Tenants}

The sentiments registered by both parties during the focus group discussions bothered on some level of assertiveness resulting from some perceived benefits either party expected from their transactions. Hostel owners were expecting student tenant to live in the hostel like co-owners and keeping the facility as clean as possible and doing what disciplined children would have done in their respective homes.

Students on the other hand, saw their stay in the hostels as residing in a commercial accommodation and their roles therein are only limited to keeping their individual rooms clean and nothing else. Promised and/or perceived services were to be provided by hostel owner or his/her staff. Cleaning of baths, toilets and sweeping the compound of the hostel among others were issues of concern in some hostels.

On this basis the Thomas-Kilmann Conflict Mode Instrument (TKI) which de-personalise conflict and resolving issues was the tool used in analysing the reports from the focus group discussions and strategies were generated to minimise, if not to eradicate, the conflicts. As Mainwaring (1999) noted, it was evident that the conflict of the parties encapsulates power and status, ideological perception, and utilisation of scarce resources.

Students were not ready to wholly accept their landlords' orders on issues they were not initially informed of such orders; thus rejecting the Landlords power over them regarding such orders. The hostel operators/owners on their part also insist that their orders must be obeyed because of the ownership interest vested in them as Landlords of the hostels. The vulnerability of the individual student-tenant who feels lonely because of the absence of his/her parents or guardians normally assume the position of being exploited / humiliated.

Mainwaring (1991) asserted that ideologically, the minority or vulnerable see the dominant ones as being of a higher or better value. The identification of who is minority or vulnerable is arguable in this situation because while the afflicted individual students see themselves as vulnerable, some landlords equally see themselves as being one against many student-tenants in his or her hostel. Aside from that, some hostel owners who have not attained tertiary education or higher, feel humiliated when challenged by their student tenants. They easily become very violent, comparing the students to their children and emphasise more on the extent of the students' disrespect to them as the cause of the conflict.

This conflict could be attributed to the utilisation of scarce resources. Students are blamed for over utilising or even wasting consumable utilities such as water and electricity in the 
hostels. During the personal interviews, a hostel owner showed me an exhibit in one of her hostel rooms. The middle of the room was baked as if they have been cooking with fire wood at that spot of the room. The explanation was that the student occupant of that room plugged and left an electric burner on at that spot and packed home during the holidays. It was after four days that it was noticed. She broke into the room and switched it off. In another unique situation a landlord had to cut off water supply to his showers because students frequently stay under the showers for over two hours. They do not only deny their colleagues to also shower, but wastefully increase his water bill during the warm weathers of the dry season. These directly affect the owners' financial resources and for that matter their profits/remuneration as entrepreneurs.

From the survey data, all the students complained of exploitation because they paid for services that were mostly not provided to them throughout the period. Eighty-one percent cited water as the common utility that hostel owners fail to supply in the past, especially during the dry season. About 13 percent complained of hostel owners adding new tenants into their rooms mid way during a trimester with complex explanations. Aside from this, six percent of the students who had their landlords co-habiting with them complained that they are made to pay for the electricity bills of their landlords' families.

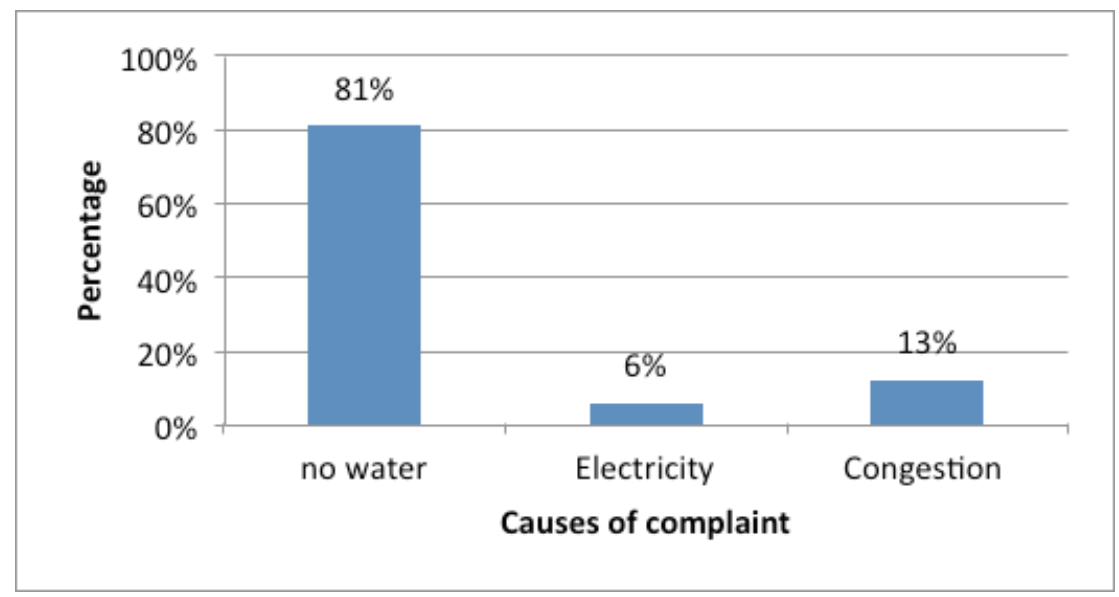

\section{Figure 5: Causes of student-tenants' complaints}

Source: Field Survey, 2013

Management, on their part, acknowledged the prevalence of conflict as a normal human factor and therefore always attempt to solve it through dialogue with the parties for a compromise. Thus applying TKI conflict management model, where a collaborative settlement is not attainable at any given case, the resident committee of the University arbitrate for a compromise. By this each party is made to trade off a portion of his/her assertiveness for cooperativeness. 


\section{Fair Value Assessment of Hostel Rent}

The demand for hostel accommodation is derived from the demand for university education and for that matter all levels of education across the country. This demand has overshadowed the needed assessment of hostels for their true value in respect of the facilities. The occupants are mostly students, and they have little or no knowledge of the fair value of the accommodation they occupy. They only console themselves with the expected knowledge and higher or better qualification they are seeking.

The theory of demand and supply explains the behaviour of buyers and sellers of goods and services based on some assumptions. The demand and/or supply of the hostel businesses, for any given academic year, as per the subject matter of the study, are fixed. That is the number of non-resident students in the University and the number of beds in each of the hostels.

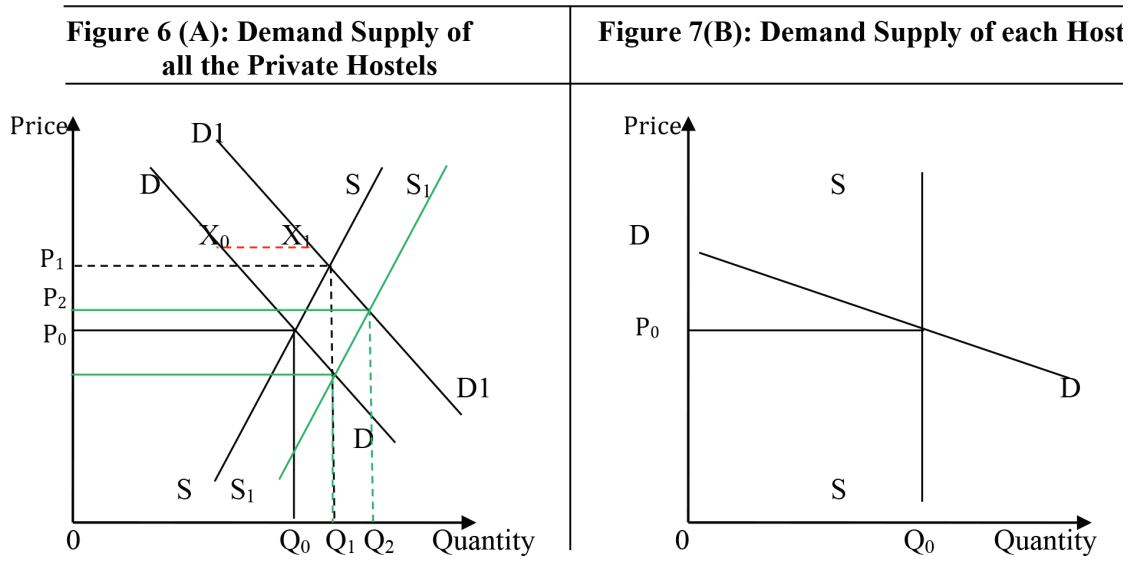

\section{Source: Field survey, 2013}

Figure 6A denotes the aggregate demand and supply of hostel services. It also demonstrates a realistic situation where the net enrolment for a given year exceeds the graduating students by $\mathrm{X}_{1}-\mathrm{X}_{0}$ resulting in a shift in demand from $\mathrm{D}$ to $\mathrm{D}_{1}$. This will force landlords to convert their non-hostel rooms to hostels to meet the increase in demand from $Q_{0}$ to $Q_{1}$. In the next opportune period the excess demand will attract new hostels that will create a shift in the supply curve to $S_{1} S_{1}$. Figure $7 \mathrm{~B}$ on the other hand, demonstrates the current demand and supply status of each hostel profiled.

Hostel owners in Navrongo, until the 2013-2014 academic year, charged varying and unrealistic rents for their rooms. Fresh students who were not privileged to have friends in the Community had to settle for any available room on arrival in Navrongo. In every hostel two major variables were fixed - number of beds and the rent per bed. The landlords wilfully predefined their rent for the purpose of the profiling, even before 
student returned to campus. The students were either to accept or reject the services at the ruling rent in each hostel. Where the demand for a given hostel exceeded the beds available, the owner cannot create new rooms and beds to meet the demand. They could not also increase the rent to take advantage of those with the ability to pay the new rent. The only discriminating factor was to allocate the beds for cash and not for credit.

The profiling and publication of the hostels, their facilities, locations, rent amount per bed in a room of $1,2,3$ or 4 occupants provided students with the opportunity to choose the hostels they desire. Out of the 40 sampled hostels 80 percent charged between GHC 450 and $\mathrm{GHC}_{50} \mathrm{O}$ per bed for a year for two in a room, > $\mathrm{GHC}_{350}$ to $\mathrm{GHC}_{4} \mathrm{OO}$ per bed for a year for 3 in a room, and GHC 280 to GHC 350 per bed for a year for 4 in a room. The only two extremely cheaper hostels which charged GHC200 and GHC250 per bed for a year for 2 in a room lacked most facilities. They both depend on a nearby borehole and use pit latrines constructed outside the hostels. Aside from these two which were fully occupied although they lacked most of the needed facilities, all the rest were occupied by students based on their facilities and the amount of rent per bed.

All the hostels are located within a radius of less than one kilometre from the heart of the university campus. Distance was therefore not a critical factor. About 90 percent of the hostels had reliable source of potable water as per figure 8 , but students preferred those with mechanised boreholes (50\%) to those connected to water company system. The other aspect is that hostels that were not rehabilitated after the previous academic year, were also not heavily patronized although they had mechanised boreholes, showers and even mattresses.

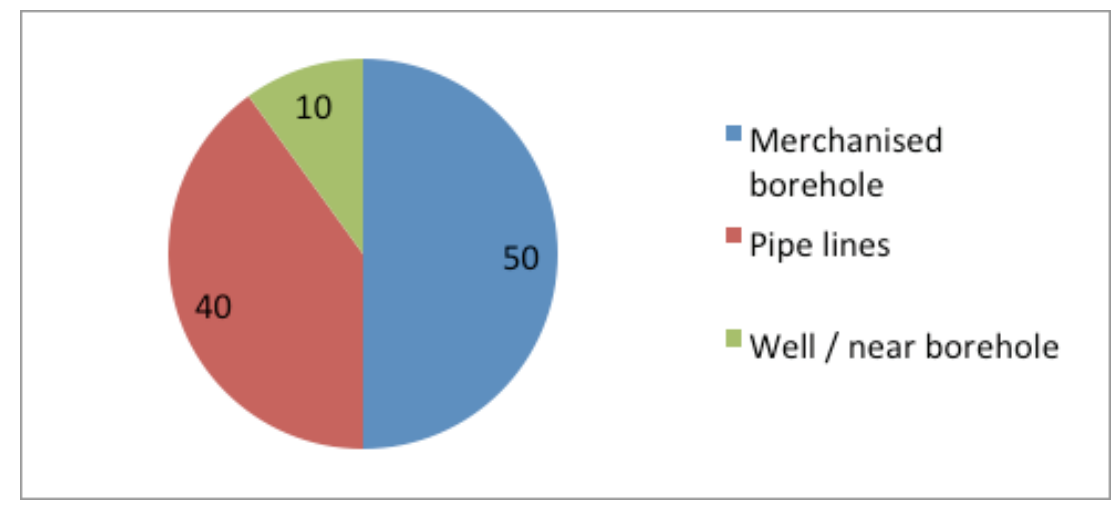

\section{Figure 8: Hostel water source}

Source: Field Survey, 2013

Higher premium was placed on hostels that provided mattresses. As per figure 9, only 20 percent of the hostels provided mattresses to their tenants. These hostels were rushed for by fresh students such that continuing students who failed to confirm their stay in these 
hostels suffered ejections. Some of the hostels that are almost inside the campus but with very poor facilities and yet were charging high rents were rejected by the students due to the availability of better ones as per the published profiles. Although students were still reporting for school at the time this report was being written, hostels that were fair in pricing their facilities were already fully occupied. Continuing students, who normally purport to be retaining their rooms in the hostels by leaving some of their unwanted clothes and later come to secretly pack out to better hostels they have identified, were displaced this time. Figure 9 shows the percentage of hostels with mattresses, water-closet toilets and showers.

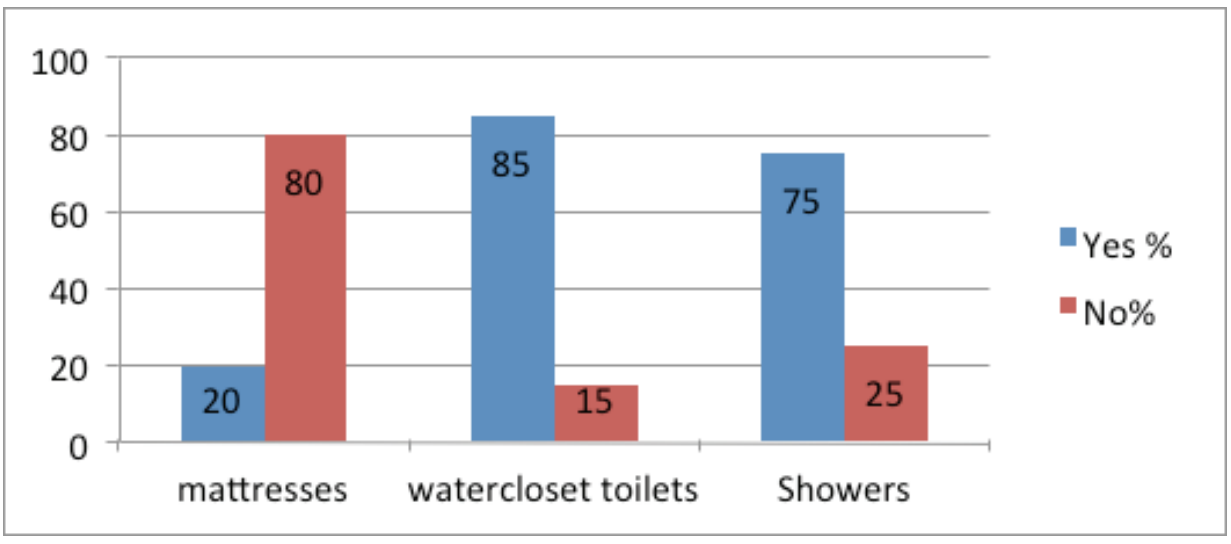

\section{Figure 9: Facilities in hostels}

Source: Field Survey, 2013

Given the intrinsic fair knowledge of hostels' market in Navrongo their fair value yields triggered a reinforcement to effectively accelerate facilities improvements. Hostel owners have begun to appreciate that the historical cost of constructing a hostel ${ }^{9}$, although necessary, is not a sufficient basis of attracting student tenants. Adequate facilities must be incorporated into it and the finishing should be attractive enough to even invite prospective tenants to inspect it.

\section{University's Duty of Care}

Assessing the role of the University in relation to the duty of care it may owe its nonresident students, empirical perceptions gathered from the field survey revealed that the University can always intervene to rescue its students from going through exploitation and humiliations. These comments were in conformity to the principles of loco parentis doctrine; landowner-invitee theory; and student-college relationship as special (Hirshberg 1994, Torts, 1965).

9 Historical cost of constructing a hostel is the amount spent in building the hostel and furnishing it to a habitable state. 
This means the university must take the necessary steps as parents of the students to protect them. The student respondents confirmed their understanding as per the student handbook that the University cannot be sued by a student for any hazard suffered by the student during any organised students welfare related event in the university. The Resident Committee Members were of the opinion that although students could not hold the university liable for a third party exploiting or humiliating them, the University owed its students a duty to protect them as long as they remain students of the University.

Private hostel owners were of the opinion that the University has a role to play in protecting the students' interest. As such they believe the University can at anytime intervene in any transaction with a student, especially concerning accommodations.

The profiling of hostels and their subsequent publication by the researcher was seen as a good basis to provide students with information on hostels to enable them make informed decisions on their choice of residence. It thus exposed the many sub-standard hostels that hitherto were charging exorbitant rents with unfulfilling service promises that generated conflicts.

By publishing the profiles of the hostels on notice boards and other public places, the strategic invisible hand of demand and supply as per the free market economy killed about 97 percent of the conflict emanating from the students seeking promised services. This is so because facilities of each hostel were inspected before recording them to the profiles (that is $87 \%$ covered). Rents were given based on the number of occupants per room. This also covers about 10 percent of the conflict, where landlords bring in additional tenants with some excuses. Landlords are very much aware that a violation of any such conditions could result in consequential actions from the University.

\section{Summary, Conclusions and Recommendations}

\section{Summary of Findings}

Most of the conflicts were interpersonal ones and were much associated with power and status, perception of one being vulnerable to the other, and the utilisation of scarce resources. Students easily challenged orders from their landlords especially if those orders were not agreed upon. Students' resistance, in most cases, were interpreted by hostel owners as arrogance because they see them as co-equals of their biological children.

Vulnerability perceptions were found to be interchangeable or applicable to both parties from case to case. Hostel owners at one time see themselves to be vulnerable in the hands of their student tenants. In some cases, the students fall prey to the vulnerability phenomenon. Using the TKI conflict analysis and resolution instrument, it was evident that at the point of conflict, both parties demonstrate high assertiveness with little or no co-operation. This put the conflicting parties in the competitiveness quadrant of the TKI instrument. Publishing the profiles of the hostels, resolved these situations. The 
students were well informed about the various facilities in each hostel, the rent per bed, and the number of persons in a room. So they freely demanded the hostels they wish to stay in, knowing very well the facilities that exist in the hostel. This solved the problem of hostel operators failing to provide for services they promised at point of entering into the tenancy agreement with their student tenants. It also resolved the problem of overcrowding without the tenants' approval. Thus rooms designated for two people at a given rent cannot be made to take in an extra tenant. Thus the free inter play of a relatively perfect knowledge of the market conditions and the invisible hand of demand and supply, settled the greatest causes of the students-hostel owners' conflict. This resolution strategy placed the parties on a win-win status (that is, the Collaborative quadrant of the TKI instrument)

The publication of the hostels profiles exhibited their various strengths and weaknesses in attracting students. The seemingly perfect knowledge of the market conditions resulted in the best quality service providers being patronised. The presence of a mechanised borehole and mattresses were the unique facilities that granted premium value to the hostels. Most continuing students who were living in the premium hostels and were very reluctant in paying for their rents could not retain their beds. The pressure of high demand on the static supply at a given price, as indicated in figure 7 (B), leaves landlords' hands tied. Their powers to determine either the number of beds to supply or the price to charge were pre-defined during the profiling. Figure 7 (B) shows a perfectly price inelastic supply (SS) curve for each hostel because the capacity of the hostel (that is, number of beds) as profiled is constant and cannot be changed over the momentum period with a ruling rent $\left(\mathrm{P}_{\mathrm{o}}\right)$. The non-variability of both the price and quantity supplied in a highly demanded hostel leaves the owner with no other choice of discrimination but to go for cash transaction.

All the sampled respondents exhibited some knowledge of the university's role as a parent to all its students. They were equally aware that students are adults and assumed responsibility for their actions and inaction. Hostel owners see the University as having all the powers to intervene on behalf of any student at any point in time and would therefore seek advice from the university in most conflict cases with a student. These all confirmed the principles of loco parentis doctrine; landowner-invitee theory; and student-college relationship as special (Hirshberg, 1994; \& Torts, 1965).

\section{Conclusions}

The findings showed that a win-win situation can be generated in the competitive conflict environment between the hostel owners and their student tenants, by moving the conflict condition from the competitive quadrant to the collaborative quadrant. The publication of the hostels' profiles which showcased the facilities and price per hostel exposed them for competition. The forces of the free market economic tool of demand and supply then effectively took over in determining the true value of each hostel bed. 
Although the university does not owe its non-resident students any duty of care and could not be liable legally for their exploitation by private hostel owners, it has the responsibility as a parent under the loco parentis doctrine; landowner-invitee theory; and student-college relationship as special to protect students from exploitation and humiliations.

\section{Recommendations}

Conflict plays a critical role in the destruction and/or building of businesses and particularly in this situation, its escalation can spell serious consequences on the University. To eradicate the information asymmetry in the private hostel market, it is recommended that the Dean of Students should encourage the Students' Representative Council (SRC) of the various campuses to profile the private hostels in their campuses and publish. The SRC should consistently update the database of the hostels' profiles before the beginning of every academic year and paste them on notice boards and at various vantage points in the campuses as well as in the internet. This would increase the accessibility of hostels information and enhance free and objective choice of hostels by students even while at home. It would encourage the hostel owners to maintain their hostels and incorporate attractive facilities so as to attract more student-tenants. This could significantly reduce the exploitation of students by hostel operators and most conflict situations, as well as reward investors equitably for their investment values.

It is further recommended that the Rent Control Office and the Ghana Tourist Board should proactively get actively involved to assess and categorise the hostels' facilities for standardisation of their facilities and rent fixing.

\section{References}

Boyer, R. (2007). Assessing the impact of fair value upon financial crises: A communication presented at the 18th Annual Meeting of SASE, Trier, June 30 to July 2, 2006. Socio Economy Review, p. 23.

Chartered Institute of Management Accountants (2010). CIMA Management Level Paper E2 - Enterprise Management, Complete Text for Nov. 2010 and May 2011 exam sittings, UK: Kaplan Publishing, pp.231-235.

Clark, L.S., Kinder P.D. \& Hotchkiss C. (1988). Law and Business, $2^{\text {nd }}$ Ed. USA: McGrawHill Inc. PP.

Curran, J. \& Blackburn, R.A. (2001). Researching the Small Enterprise. London: Sage.

Davis, T. (1992). Examining Educational Malpractice Jurisprudence: Should a Cause of Action Be Created for Student-Athletes? 69 DENY. U. L. REV. 57, 85. 
Hirshburg, P.M. (1994). In Loco Parentis in the 1990's, 46 WASH. U.J. UPn. \& CONTEMP. L. 189,194 .

Mainwaring S. (1999). Management and Strategy. London: Pearson Professional Limited

McGirt, M. D. (1999). "Do Universities Have a Special Duty of Care to Protect StudentAthletes from Injury," Jeffrey S. Moorad Sports Law Journal: Vol. 6: Iss. 1, Article 8.

Ornstein J.K., (1996). Broken Promises and Broken Dreams: 6 SETON HALLJ. SPORT L. 641, 657.

Robson C. (2002). Real World Research ( $2^{\text {nd }}$ Ed). Oxford: Blackwell.

Tashakkori, A. and Teddlie, C. (Eds) (2003). Handbook of Mixed Methods in social and Behavioural Research, CA: Thousand Oaks, Sage.

Torts, (1965). Provisions 314A, 320, Jeffrey S. Moorad Sports Law Journal: Vol. 6: Iss. 1, Article 8. pp. 219-230.

Whiting, B. \& Whiting J. (1973). Methods of Observing and recording behaviour. In Naroll, R., Cohen, R. (Eds), A Handbook of Method in Cultural Anthropology. London: Colombia University Press. 